\title{
“THE ABOLITION OF ETHNIC, RACIAL, OR CULTURAL DISTINCTIONS IN THE APOSTLE PAUL. INDICATIVE PATRISTIC APPROACH."1
}

\author{
Soultana Lamprou - Viera Zozul'aková
}

DOI: 10.17846/CL.2019.12.2.33-42

\begin{abstract}
LAMPROU, Soultana - ZOZULAKOVÁ, Viera. The Abolition of Ethnic, Racial, or Cultural Distinctions in the Apostle Paul. Indicative Patristic Approach. The study focuses on Paul's Epistle to the Galatians 2:28, wherein Paul, the Apostle to the Gentiles, proceeds to a declaration of human rights by stating: "There is neither Jew nor Greek, there is neither slave nor free, there is neither male nor female; for you are all one in Christ Jesus". Patristic interpretations regarding this position of the Apostle Paul are cited, according to which Paul's basis is Christocentric, and is a criterion for the transposition and dissolution of each type of distinction, and the change of human relationships is the transformation of the world into the Church of Christ. Moreover, it is also emphasised and presented, in Christian literature, while the phenomenon of each type of distinction is engaged pastorally in the works of the Fathers and ecclesiastical authors, each is considered from a different perspective and approached pastorally.
\end{abstract}

Keywords: community, identity, tribal distinctions, racism, "separation system", Apostle Paul, Epistle to the Galatians, Jesus Christ, Holy Spirit, Divine Economy, christian community, patristic literature

Abstrakt: LAMPROU, Soultana - ZOZULAKOVÁ, Viera. Zrušenie etnických, rasových alebo kultúrnych rozdielov v myslení apoštola Pavla. Indikatívny patristický prístup. Štúdia sa zameriava na Pavlov list Galatským 2, 28, v ktorom Pavol, apoštol pohanov, vydáva takéto vyhlásenie o ludských právach: „Nie je ani Žid ani Grék, nie je ani otrok ani slobodný, nie je muž ani žena; pretože ste všetci jedno v Kristovi Ježišovi." Autorky uvádzajú patristické interpretácie týkajúce sa vyjadrenia apoštola Pavla, podla ktorých je Pavlove stanovisko kristocentrické a je kritériom pre transpozíciu a zrušenie každého rozlíšenia. V krestanskej literatúre sa zdôrazňuje zmena ludských vztahov, ktorá je premenou sveta na Kristovu cirkev. Fenomén rozlišovania je analyzovaný v dielach Otcov a cirkevných autorov. Každý typ odlišnosti, rozdielu je posudzovaný $\mathrm{z}$ inej perspektívy a podla toho sa $\mathrm{k}$ nemu pristupuje.

Klúčové slová: ludské práva, komunita, identita, kmeňové rozdiely, rasizmus, „separačný systém", apoštol Pavol, list Galatským, Ježiš Kristus, Svätý Duch, Božia ikonómia, krestanské spoločenstvo, patristická literatúra

This work was supported by the Slovak Research and Development Agency under the contract No. APVV-16-0116. 


\section{Introduction}

In structured communities the socialization of man begins at his birth and continues throughout his life. This process shapes the personality by accepting the norms set by society. "It designates the internalization of value-orientations, norms and symbolic meanings as well as acquisition of social and practical skills by social learning and training." (Heinz 2002, 41). The need for man to be included in a social group brings about differentiation and gives meaning to his attempt at recognition and, even more so, the acquisition of his identity.

However, when differentiation takes on the dimensions of a different critique and confrontation between people belonging to different races, genders, sexes, classes, just as the dimensions of judgment in the relationship of cohabitation between groups of people, then it is called racial, gender, social, discrimination correspondingly and includes elements of racism, which is unfortunately emphatically recorded in modern times despite our so-called progressive age. Daniel Payne examines the conception of human rights in the work of one of leading Greek intellectuals, Christos Giannaras, and he points out together with Giannaras that the concept of human rights is a product of modernity. While the concept of "right" began to develop in the Middle Ages, it was not until the modern age that the concept began to be used as we know it today. (Marsh 2012, 204). "The radical innovation of modernity lies in the fact that modernity made rights "human" that is, common to all humans, without discrimination", explains Giannaras (1998, 83). There is a question why the human rights can be violated so often and in an easy way, why the terms can be misused for somebody egoistic aims as we witness in the contemporary society. The answer can be seen in very strong individualism that has been developed in the modern and postmodern society which stresses the individual rights and life reduced from moral responsibility. People could be equal, but in fact they are not in many ways. Distinctions constitute the application of "systems of segregation", which don't recognize equality in certain groups and the equal rights in social and cultural expressions of society (Gioultsis 2011, 334-335).

\section{The abolition of ethnic, racial, or cultural distinctions}

Considering the apostolic times and the early Christian literature, such values as equality, tolerance, dignity and respect for others are among the main topics. Paul, the Apostle to the Gentiles, in his Epistle to the Galatians, succeeds in the abolition of every "system of segregation" when he proceeds to preach about human rights, in which however, the social structures of society different than the established ones arise with clarity- the structures of the Christian society. According to the Christian tradition "a human being preserves his God-given dignity and grows in it only if he lives in accordance with moral norms. There one can find direct link between human dignity and morality, that personal dignity implies the assertion of personal responsibility. The dignity of human person, then, is found in the use of the human will as it responds to the will of God. In particular, this dignity of the person is demonstrated in the social world in which man lives as he shows his love for his fellow man, revealing the principle of togetherness of the human person." (Marsh 2012, 204).

"There is neither Jew nor Greek, there is neither slave nor free, there is neither male nor female: for you are all one in Christ Jesus." (Galatians 3: 28). Paul's revolutionary teaching shocks the early Christian community.

Paul is aware of the difference between Jews and Greeks (2 Corinthians 11: 22. Galatians 2: 1415; 3, 1. Philippians 3: 5). He, a Jew himself, knows that Jewish identity is connected to a common heritage, history, culture, and religion. However, the role of religion, of the Mosaic law, is critical, 
as long as in the closed Jewish group all who would adopt the Jewish way of life (in the case of the convert) could be included.

The commandment, however, of the resurrected Lord to his Apostles to "Go therefore, and teach all nations" (Matthew 28: 19), Go into all the world, and preach the gospel to every creature" (Mark 16: 15), and also the personal revelation of his mission by the Lord "Go, for I will send you far away unto the Gentiles"(Acts of the Apostles 22: 21), makes Paul's mission towards the Gentiles greater after his calling by the Lord on the road to Damascus, the moment of course when the organization of Roman society (the Roman imperium), of which Paul was a citizen, made possible by the system of acquirable citizenship which was devised to unite the people, gives the context for the the fulfillment of his missionary work.

Thus, as has otherwise correctly been pointed out, "on the road to Damascus Christ offered to his Church the ecumenical teacher and father, who would fracture the bonds of Jewish isolationism and exclusivity and, as a mighty soaring eagle, bring the gospel message to the ends of the earth." (Zisis 2004, 27).

In his course, however, he must confront the ethnophyletism of his own people in regards to the issue of the reception of uncircumcised Gentiles into the Church, despite the fact that this theme had been addressed and resolved by the Apostolic Council. Paul exerts his more austere judgment against the judaising teachers in his Epistle to the Galatians, because they are disturbing the newly established churches of Galatia by preaching the need to follow the restrictions of the Law, notably circumcision, for the salvation of the faithful, while attacking his apostolic authority with slander. Moreover, he points out the grave danger that the Galatians are in if they disregard the Gospel revealed by Jesus Christ which had already been preached to them. The mission of the Law is considered by Paul to have already been fulfilled in the plan of Divine Economy. Thus, he contrasts the preparative and pedagogical role of the law, which held them prisoner in preparation for Christ, with the freedom that the Lord offers with his sacrifice on the Cross and Resurrection, redeeming mankind from the curse of the transgression of the law. The granting of the Holy Spirit, adoption, and salvation by grace is realized only by faith in Jesus Christ and not by the Law. He discourages the return to the law, because "For in Christ Jesus neither circumcision nor uncircumcision counts for anything, but rather a new creation" (Galatians 6: 15).

The basis of the Paul's Gospel is christocentric. It functions for the upbringing of the spiritual condition of the world and its transformation into the Church of Christ (Papadopoulos 2009, 101). Demanding the restoration of humanity into a new creation, it transforms the conscience of a way of life with the starting point being the common faith in Christ and continual participation in His body in the Church, where social, tribal, ethnic, and racial distinctions are broken down and the social status quo in human relationships is radically transformed (Mantzaridis 2015, 304).

Paul abolishes the law, yet reveals the splendour of divine grace. In faith in Christ and also in the transformation of mankind by his participation in the Mysteries of the Church, man's freedom and equality are established and every kind of distinction is abolished, inasmuch as "You are all one in Christ Jesus" (Galatians 3: 28. Compare Karavidopoulos 2000, 110-113).

The Christian identity that Paul establishes, without of course wanting to eliminate differences, dominates, and is higher, because it encompasses the others. It has the following characteristics: common heritage, inasmuch as the children of Abraham are no longer considered according to the flesh, but his descendents by faith (Galatians 3: 7-9; 14. Compare Kolovopoulou 2007, 166), a common homeland, Jerusalem from a spiritual and eschatological perspective, and a common body, as sons of God in Jesus Christ in the one body of the Church. The bond with which the Holy 
Spirit unites Christ with the baptized and all of the believers to one another in the body of Christ, in the context of salvation in Christ, is so great that it transcends all distinctions.

It's worth noting the way in which the holy martyrs of the Church encapsulate us, just as it is characteristically written in the Martyria, the Pauline theology about Christian identity, when replying to whatever question asked by their persecutors relating to the race, their ancestry or their social class, they exclaimed "I'm a Christian" (Lamprou 2004, 154).

In Christian literature, the phenomenon of every form of distinction is addressed pastorally in the work of the Fathers and Writers of the Church. It is both considered from a different perspective and is approached spiritually.

Focusing on the prayer in Gal. 3:28 "There is neither Jew nor Greek, there is neither bond nor free, there is neither male nor female: for all of you are one in Christ Jesus", we look at what is recorded in Ecclesiastical literature to give an example, because of the period of time, the mode of approaching it by the Fathers and Church Writers, and thematology, in which hermeneutics is also included.

Pauline requirements regarding the relations of man and woman (Ephesians 5:22-23), master and servant (Ephesians 6: 5-9) are found in the works of the Apostolic Fathers, while drawing attention to the Churches, because of the danger of heresies, the need for coming together around the bishop, they briefly cite the truths of the Christian faith and include evangelical admonitions for the peaceful and virtuous life to the members of the body of the Church. Ignatius the God Bearer in particular, advising the masters to take care of their servants, sets St. Job as the example, and emphasizes that there is "...one nature and one race of mankind. For in Christ there is neither

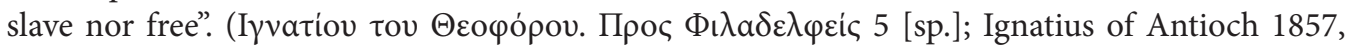
825A).

When the fathers talk about the creation of man according to the image and likeness of God they consider the distinction of sexes, the "male and female created he them" to be something other, as Paul bears witness to, outside of the divine prototype and refers to the peculiarities

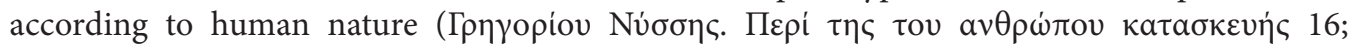
Gregory of Nyssa 1863, 181A-D). Consequently the creation of mankind according to the image and likeness of God - the basic starting point of Biblical anthropology - doesn't justify any distinction theologically (Karavidopoulos 2008, 227).

In patristic literature differentiation is defined by the reception or not of the redeeming Gospel of Christ and of the life in Christ, and whatever distinction doesn't have ethnophyletistic or any other another kind of dimension other than that which is only soteriological.

In order for the created and limited to find freedom in the nature of man, he obeys the will of God, he becomes His slave, in which according to Gregory Palamas there is uncreated and absolute freedom, because "The Existing One conceived all being in himself" ( $(\pi \dot{\varepsilon} \rho \tau \omega \nu$


participates in true divine freedom (Mantzaridis 2015, 257-259). Consequently Paul's message would have to be viewed on the basis not of the visible but that which is to come.

Man becomes a son of God through faith, as the manner, of course, of adoption and his [re] birth is indicated by the mystery of Baptism, in which he puts on Christ (Iwávvov Xpvoootónov.

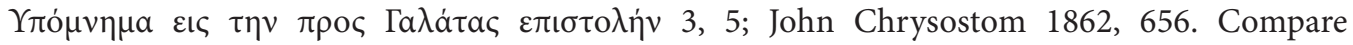

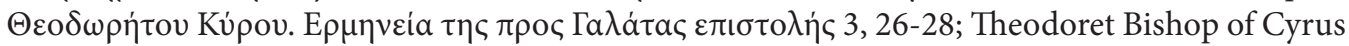
1864, 484CD).

Union with Christ becomes clearer, closer, and deeper when all become, according to Paul, one in Jesus Christ, that is to say they have one form, one type, that of Jesus Christ. "So, how then," asks Nicodemus the Hagiorite, "does such a thing occur? Perhaps according to an external

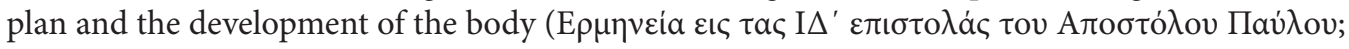


Nicodemus the Hagiorite 1990, 297), answered through the lips of Gregory of Nyssa, "For of those things which are before our eyes nothing is altered: the characteristics of the body remain unchanged, and the mould of the visible nature is nowise different. But there is certainly need of some manifest proof, by which we may recognize the new-born man, discerning by clear tokens the new from the old. And these I think are to be found in the intentional motions of the soul, whereby it separates itself from its old customary life, and enters on a newer way of conversation, and will clearly teach those acquainted with it that it has become something different from its former self, bearing in it no token by which the old self was recognized." (Eıৎ $\tau \eta \nu ~ \eta \mu \varepsilon \dot{\varepsilon} \propto \nu \tau \omega \nu$

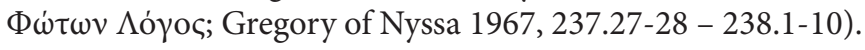

According to Basil the Great, exactly just as the board which is intended to become an image of the king, whether it is from wood or from clay or silver or another material, needs to caste away every irregularity and unevenness in the process and then be accepted from above, to take the form of a royal image. - And certainly in this stage of the process, the difference between the wood or of the clay or of the silver is no longer recognized, because the exactitude of the image which it shares with the prototype draws the attention of all and masks any difference in the material. Thus, also the baptized, whether Jew or Greek, whether man or woman, whether slave or free, whether Scythian or barbarian, because he has cast aside the old man with his actions and by means of the spiritual teaching of Christ, needs to be clothed in the new and in this way reach


Nevertheless, the miraculous and awe-inspiring aspect of this union, St John Chrysostom explains, is that the Greek and the Jew, and the ex-slave, don't have the form of the angel or archangel, but rather of that of the Lord of all, and live with Christ present within themselves and are imitating



Of course within the Church, which is the image of God, and by the participation in the mysteries the union of its members with God is enabled equally even if the unified people

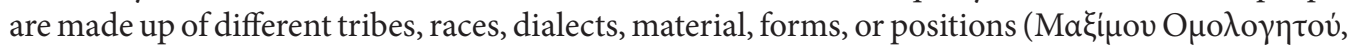

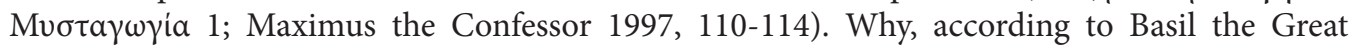
"the members of the human race are different from one another; but the spiritual race all are one". Here, the common father is God and all are siblings - not in the flesh, but from the adoption of the Spirit - and they dwell together in love and oneness of mind. Thus it is set for a common goal and common struggles and for the attainment of holiness and salvation (Eıৎ tovs ájıvৎ

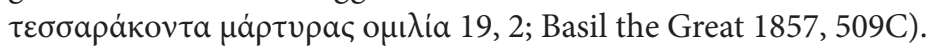

Maximus the Confessor allegorically explaining the passage in the speech, names "anger" "male", "desire" he names "female", "Jew" he calls those who follow the monarchy of a single-person God, and "Greek" he calls those who follow the polyarchy of polytheism. Consequently in Christ Jesus there is no male nor female, meaning "anger and desire", which while tyrannizing the thoughts and taking the reason out of the law of nature, because of the higher faculty of its nature chooses the alluring things and consequently prefers the flesh to the spirit. In Jesus Christ there aren't, namely, the marks and passions from corruption and human nature, rather only the godlike reason, which creates divine knowledge and its only motivation is towards virtue. Neither Greek nor Jew, which denotes the different message of the true God, deprived of the Word and His Spirit, - likewise contrary towards him. Neither barbarian nor Scythian, is the distinction which rebels as against the one nature of humanity, the consequence of which was the unnatural law of men murdering one another. Neither slave nor free, is this distinction of the same nature, which considers equality according to nature worthless and has the law as its aid, which comes from the tyrannical disposition of those who are stronger in opposition to, however, man "according to the image of God". Yet all

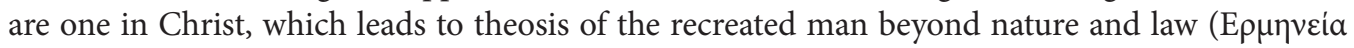




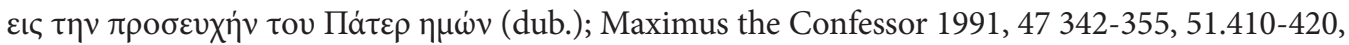
55.478-487).

Male, female, barbarian, Scythian, slave, and free make up, in patristic literature, aspects of the flesh which are abolished by the great mystery, according to which God who became man and impoverished for our sake resurrects the flesh with the intention that we all become one in Christ and that we take only the divine character, and that we take on the greatest and most

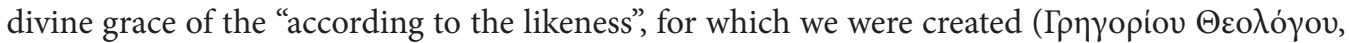

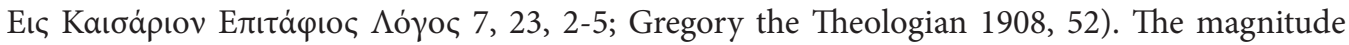

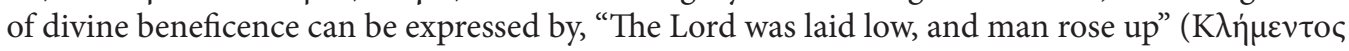

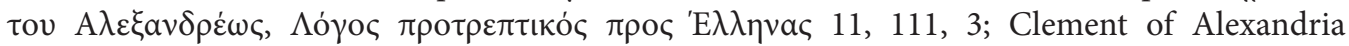
1949, 179) and having received Christ becomes, "new, a new creation in God the Holy Spirit. And as Christ is not divided, neither are barbarian nor Jew nor Greek, nor is there male nor

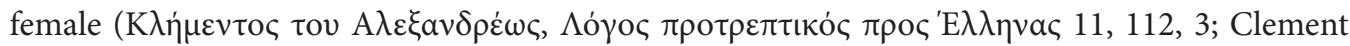
of Alexandria 1949, 180), and thus man in Christ does not is not approached as slave or free,

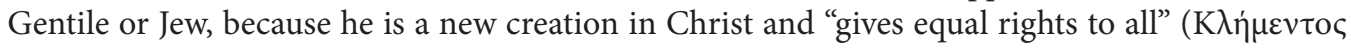

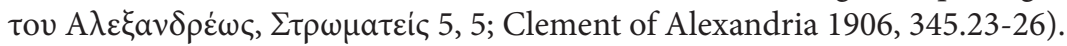

It is noted, of course, that the renewed man which has distanced himself from the filthy passions, such as vainglory and hypocrisy, has been healed from anger by almsgiving, he has cleansed the mind by prayer, he has curbed desires by fasting, it is not apportioned, to male and female, nor Greek and Jew, barbarian or Scythian because of dispassion, to the circumcised because of one faith and love, moreover, and to the uncircumcised, slave and free, because "You are all one in Christ"

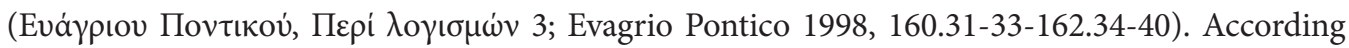
to this message the man who is both perfect in love and dispassionate doesn't know the difference between the familiar and the foreign, believer and unbeliever, slave and free, wise and unwise, male

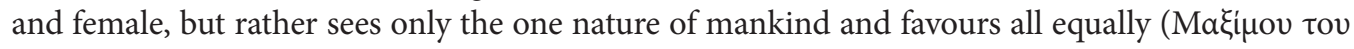

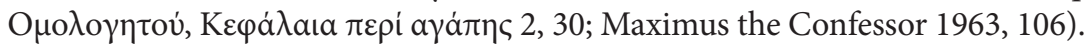

According to Chrysostom every kind of distinction makes up an anomaly of the value of life and is repealed in Jesus Christ, according to the standard of Apostle Paul, who regarded indiscriminately all slaves and free, rich and poor, barbarians and Scythians, wise and unwise, officials and civilians with the common noun "brother", clearly indicating his love (Eıৎ to a Chrysostom 1862, 246). This father reproaches the event/fact that the name "slave" or "servant"

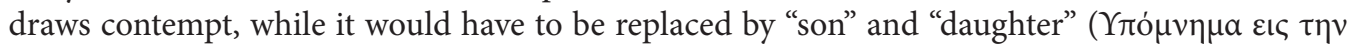

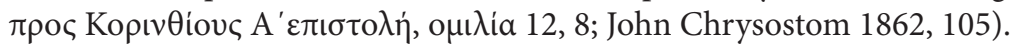

Interestingly present in patristic literature is the connection of the passage with equal participation, regardless of gender, of men and of women in the spiritual struggle for the acquisition of virtue, just as with the equal distribution of common rewards - of the kingdom of heaven, of the evergreen crown, of life eternal - to the contenders by the master of the games, Christ



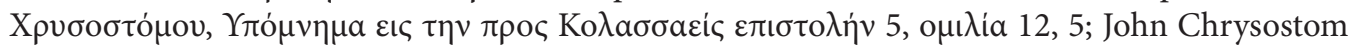

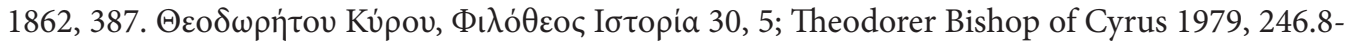
17). Chrysostom, spurred by the Pauline passage, characteristically mentions that "...here, since the contest is wholly concerning the soul, the lists are open to each sex, for each kind the theatre is arranged" and neither nature, nor illness of body, neither age can impede those following

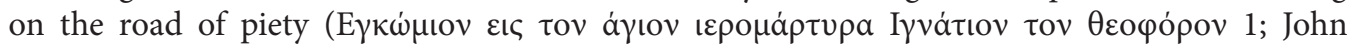
Chrysostom 1862, 587). 


\section{Conclusion}

In conclusion, the commandment of the Lord and the teaching of Paul that both distinctions are abolished and all men are equal and equal in value amongst themselves in the person of Christ and in the Church, is especially relevant today in an epoch of social changes and reclassifications.

It has been said that the problem with distinctions, more than the political and economic issues - at its core, is an ethical and spiritual one (Gioultsis 2011, 344). The concern of identity "has arisen because of the imperative under globalization to theorize people as possessing identities that are extremely adaptive to social change. As a result, there is an inherent contradiction between a valuing of identity as something so fundamental that it is crucial to personal well-being and collective action, and a theorization of identity that sees it as something constructed, fluid, multiple, impermanent and fragmentary." (Bendle 2002, 1-2). Ethnic and racial characteristics, and cultural and social differences are superficial, given that behind all of that there is man, the image of God (Gioultsis 1988, 367).

\section{REFERENCES}

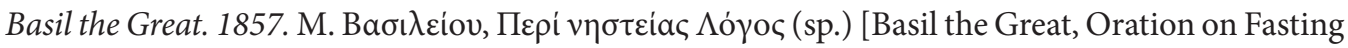
(sp.)] In Migne, Jacques - Paul (ed.). Patrologiae Cursus Completus. Series Graeca, Tomus XXXI. Paris, 1508-1509.

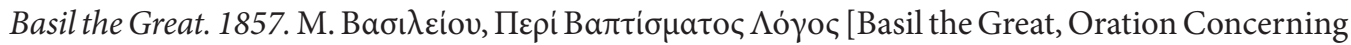
Baptism] In Migne, Jacques - Paul (ed.). Patrologiae Cursus Completus. Series Graeca, Tomus XXXI. Paris, 1513-1577.

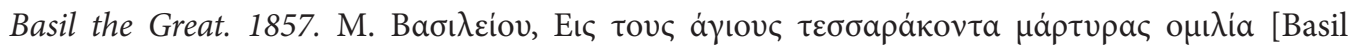
the Great, A Homily Concerning the Holy Forty Martyrs] In Migne, Jacques - Paul (ed.). Patrologiae Cursus Completus. Series Graeca, Tomus XXXI. Paris, 508-525.

Bendle, F. Mervyn. 2002. The crisis of identity in high modernity. In British Journal of Sociology LIII/1, 1-18. DOI: 10.1080/00071310120109302, ISSN 1 468-4446 (online).

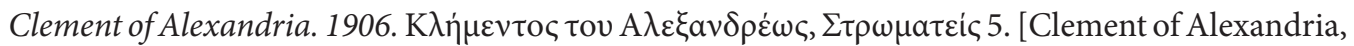
Stromata V]. In Stählin, Otto. Die Griechischen Christlichen Schriftsteller der ersten drei Jahrhunderte. Clemens Alexandrinus, Stromata Buch I-VI.Leipzig, 326-421.

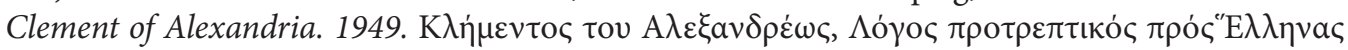
[Clement of Alexandria, Hortatory Oration to the Hellenes]. In Mondésert, Claude (ed.). Clément d' Alexandrie, Le Protreptique. Sources Chrétiennes II. Paris, 52-193.

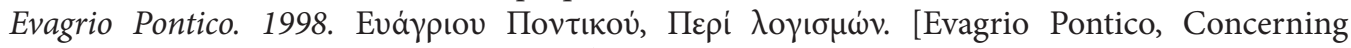
Thoughts]. In Géhin, Paul et al. (eds.). Évagre le Pontique, Sur les Pensées. Sources Chrétiennes 438. Paris, 148-300.

Giannaras, Christos. 1998. The Inhuman Character of Human Rights. Athens.

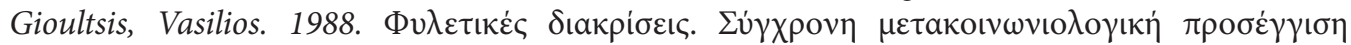

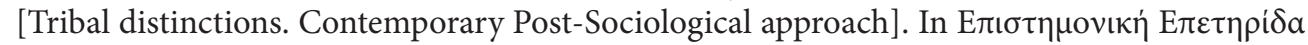

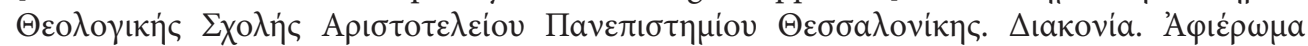

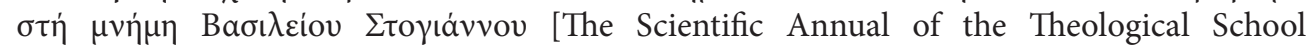
of the Aristotelian University of Thessaloniki. Diakonia. Dedication to the memory of Vasilios Stogiannos]. Thessaloniki. 357-367.

Gioultsis, Vasilios. 2011. General Sociology. Thessaloniki. 


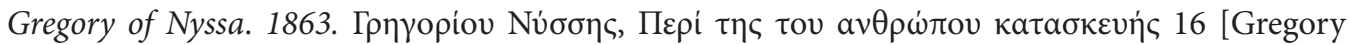
of Nyssa, On the creation of man 16]. In Migne, Jacques - Paul (ed.). Patrologiae Cursus Completus. Series Graeca, Tomus XLIV. Paris, 177-185.

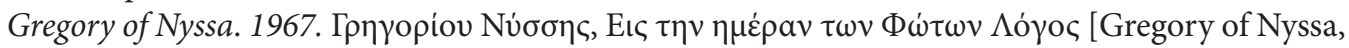
Oration Concerning the Day of the Lights]. In Gebhardt, Ernestus (ed.). Gregorii Nysseni opera, vol. IX. Leiden, 221-242.

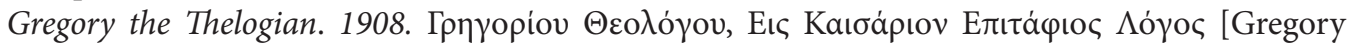
the Theologian, Funeral Oration to Caesarios]. In Boulenger, Fernand. Grégoire de Nazianze. Discours funèbres en l'honneur de son frère Césaire et de Basile de Césarée. Paris, 2-56.

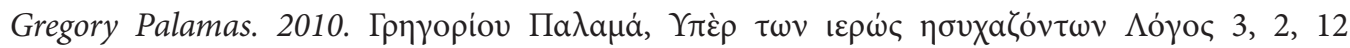
[Gregory Palamas, Homily for the Sacred Hesychasts III, II, XII]. In Christou, Panagiotis (ed.).

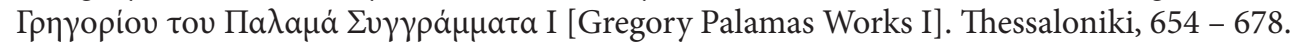

Heinz, R. Walter. 2002. Socialization Theory is dead - long live the Life Course? The transformation of a concept. In: Advances in Life Course Research VII, 41 - 64.

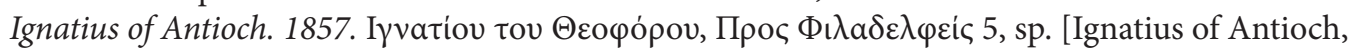
Epistle to the Philadelphians, sp.]. In Migne, Jacques - Paul (ed.). Patrologiae Cursus Completus. Series Graeca, Tomus V. Paris, 817-840.

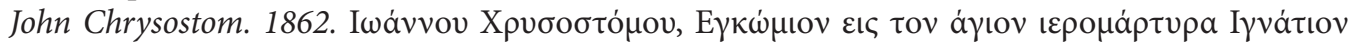
tov $\theta \varepsilon o \varphi$ ópov [John Chrysostom, Encomium to the Holy Martyr Ignatius the Godbearer]. In Migne, Jacques - Paul (ed.). Patrologiae Cursus Completus. Series Graeca, Tomus L. Paris, 587-596.

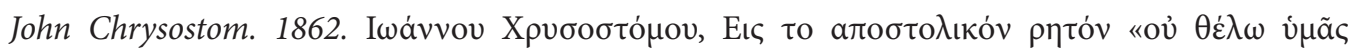

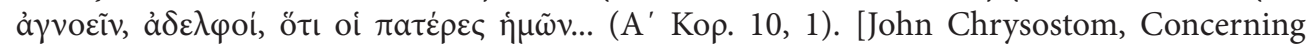
the Apostolic saying "Moreover, brethren, I do not want you to be unaware that all our fathers...” (1 Corinthians 10:1)]. In Migne, Jacques - Paul (ed.). Patrologiae Cursus Completus. Series Graeca, Tomus LI. Paris, 241-252.

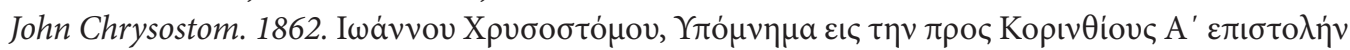
[John Chrysostom, Commentary of the Epistle of the Apostle Paul to the Corinthians]. In Migne, Jacques - Paul (ed.). Patrologiae Cursus Completus. Series Graeca, Tomus LXI. Paris, 9-382.

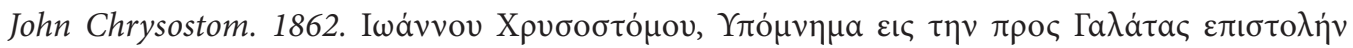
[John Chrysostom, Commentary of the Epistle of the Apostle Paul to the Galatians]. In Migne, Jacques - Paul (ed.). Patrologiae Cursus Completus. Series Graeca, Tomus LXI. Paris, 611-682.

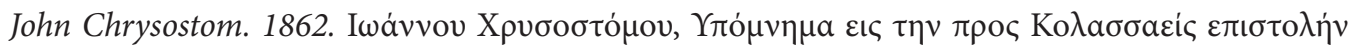
[John Chrysostom, Commentary of the Epistle of the Apostle Paul to the Colossians]. In Migne, Jacques - Paul (ed.). Patrologiae Cursus Completus. Series Graeca, Tomus LXII. Paris, 299-392.

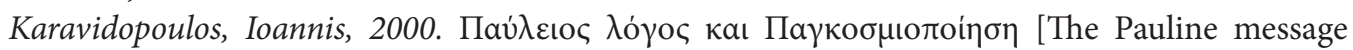

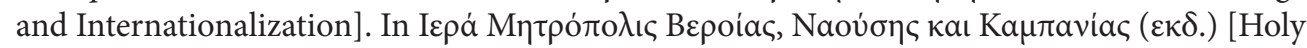

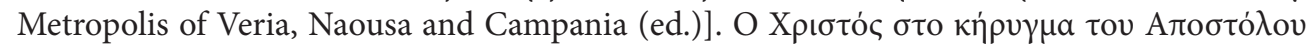

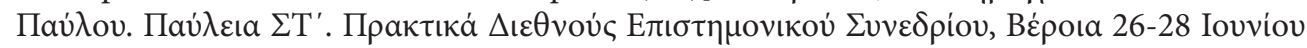
2000 [Christ in the preaching of the Apostle Paul. 6th Pauleia. Proceedings of International Scientific Conference, Veria 26 - 28 Juni 2000]. Veria, 105-116.

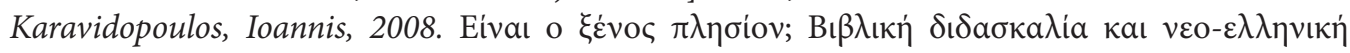
$\pi \rho \alpha \gamma \mu \alpha \tau \iota \kappa o ́ \tau \eta \tau \alpha$ [Is the foreigner a "neighbour"? Biblical teaching and contemporary reality

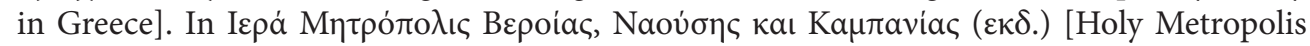

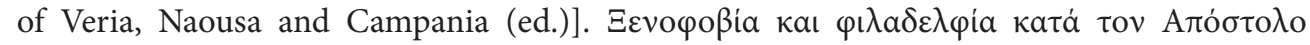




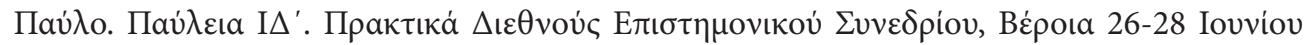
2008 [Xenophobia and brotherly love according to St. Paul. 14th Pauleia XIV. Proceedings of International Scientific Conference, Veria 26 - 28 Juni 2008]. Veria, 223-231.

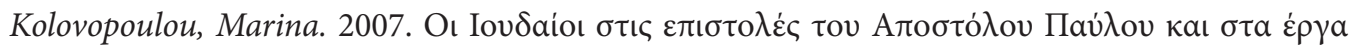

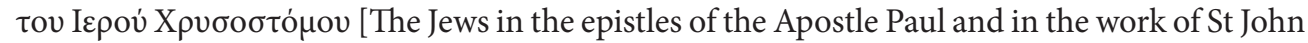

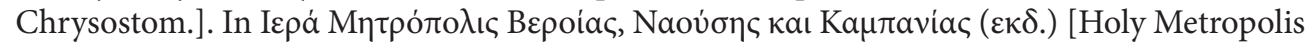

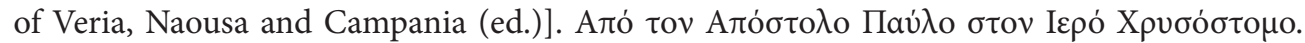

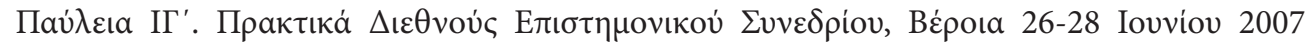
[From the Apostle Paul to St John Chrysostom. 13th Pauleia. Proceedings of International Scientific Conference, Veria 26 - 28 Juni 2007]. Veria, 163-176.

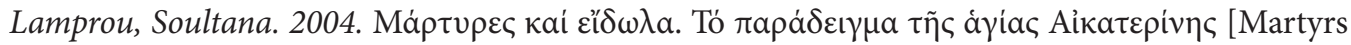

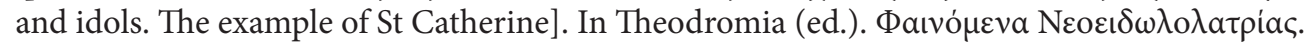

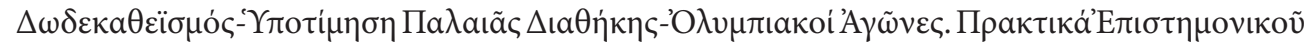
$\Sigma v v \varepsilon \delta \rho i o v, \Theta \varepsilon \sigma \sigma a \lambda o v i \kappa \eta ~ 25-27$ Maïov 2003 [The appearances of Neo-Idolatry. The religion of the Twelve Gods-Devaluation of the Old Testament- The Olympic Games. Proceedings of Scientific Conference, Thessaloniki 25 - 27 May 2003]. Thessaloniki, 151-163.

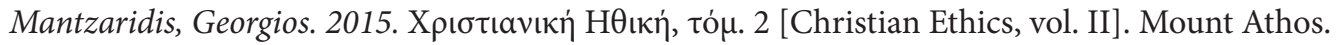

Marsh, Christopher - Payne, Daniel. 2012. Religiosity, Tolerance and Respect for Human Rights in the Orthodox World. In: Brüning, Alfons - Zweerde, Evert (eds.). Orthodox Christianity and Human Rights. Eastern Christian Studies 13. Leuven - Paris - Walpole, MA, 201-2014.

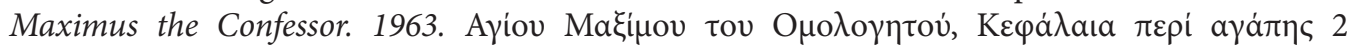
[Maximus the Confessor, Chapters on love 2]. In Ceresa-Gastaldo, Aldo (ed.). Massimo confessore. Capitoli sulla carità. Roma, 90-142.

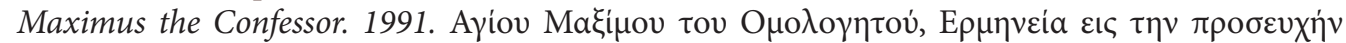

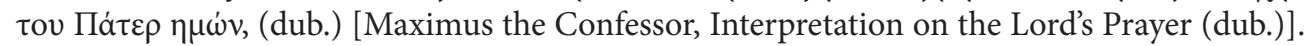
In Deun, Peter (ed.). Maximi Confessoris opuscula exegetica duo. Corpus Christianorum Series Graeca XXIII. Turnhout, 27-73.

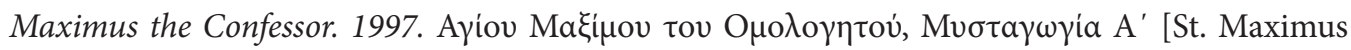

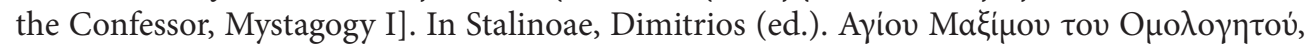

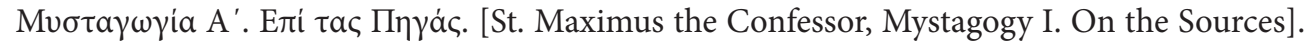
Athens, 92-256.

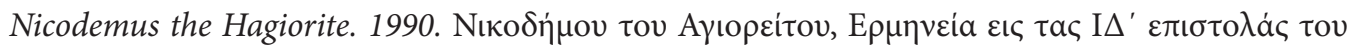

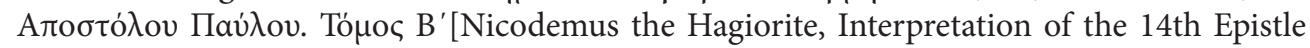
of the Apostle Paul. Tomus II]. Thessaloniki.

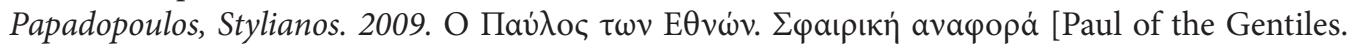

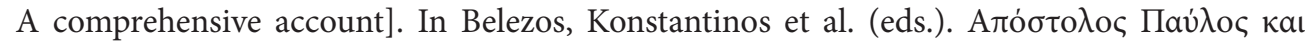

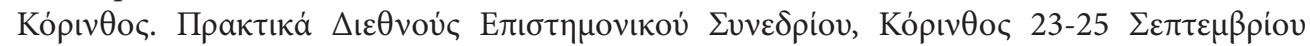
2007, тó $\mu$. A' [Apostle Paul and Corinth. Proceedings of International Scientific Conference, Corinth 23 - 25 September 2007, vol. I]. Athens, 91-125.

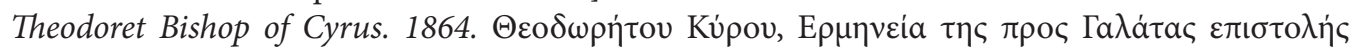
[Theodoret Bishop of Cyrus, Interpretation of the Epistle to the Galatians]. In Migne, Jacques Paul (ed.). Patrologiae Cursus Completus. Series Graeca, Tomus LXXXII. Paris, 460-504.

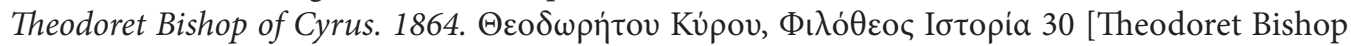
of Cyrus, Philotheos History 30]. In Canivet, Pierre - Leroy-Molinghen, Alice (eds.). Théodoret de Cyr, Histoire des Moines de Syrie "Histoire Philothée" XIV-XXX. Tomus II. Paris, 240-250.

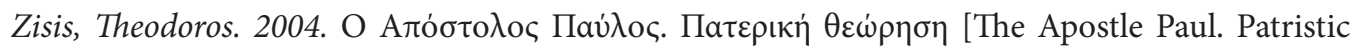
approach]. Патєрıкá 7 [Paterika 7]. Thessaloniki. 
Zozulak, Ján - Valčo, Michal. 2018. Byzantine Philosophy of the Person and its Theological Implications. In Bogoslovni vestnik. Theological Quarterly. Ephemerides theologicae 78/4, 1037-1049.

\begin{abstract}
SUMMARY: THE ABOLITION OF ETHNIC, RACIAL, OR CULTURAL DISTINCTIONS IN THE APOSTLE PAUL. INDICATIVE PATRISTIC APPROACH. The study focuses on Paul's Epistle to the Galatians 2:28, wherein Paul, the Apostle to the Gentiles, proceeds to a declaration of human rights by stating: "There is neither Jew nor Greek, there is neither slave nor free, there is neither male nor female; for you are all one in Christ Jesus". Patristic interpretations regarding this position of the Apostle Paul are cited, according to which Paul's basis is Christocentric, and is a criterion for the transposition and dissolution of each type of distinction, and the change of human relationships is the transformation of the world into the Church of Christ. Still, it is stressed that the abolition of every 'system of division' was achieved by Paul when he clearly laid out the social structures of a different society - a Christian one. Thus, in patristic literature the differentiation is determined by the acceptance or not of the redeeming Gospel of Christ and of the Life in Christ, and by whatever distinction that did not have ethnophyletistic or any other types of dimensions outside of simply the soteriological ones. Moreover, it is also emphasized and presented, in Christian literature, while the phenomenon of each type of distinction is engaged pastorally in the works of the Fathers and ecclesiastical authors, each is considered from a different perspective and approached pastorally.
\end{abstract}

Soultana D. Lamprou ThDr.

Associate Professor

Aristotle University of Thessaloniki

Faculty of Theology

Department of Holy Scripture and Patristics

Faculty of Theology - School of Pastoral and Social Theology

54124 Thessaloniki

Greece

slabrou@past.auth.gr

Viera Zozulaková, Ph.D.

Constantine the Philosopher University in Nitra

Faculty of Arts

Department of Sociology

94901 Nitra

Slovakia

vzozulakova@ukf.sk 